University of Nebraska - Lincoln

DigitalCommons@University of Nebraska - Lincoln

1985

\title{
Permeability Versus Depth in the Upper Oceanic Crust' In Situ Measurements in DSDP Hole 504B, Eastern Equatorial Pacific
}

Roger N. Anderson

Columbia University, anderson@Ideo.columbia.edu

Mark D. Zoback

U.S. Geological Survey, zoback@stanford.edu

Stephen H. Hickman

U.S. Geological Survey

Robin L. Newmark

Columbia University

Follow this and additional works at: https://digitalcommons.unl.edu/usgsstaffpub

Part of the Earth Sciences Commons

Anderson, Roger N.; Zoback, Mark D.; Hickman, Stephen H.; and Newmark, Robin L., "Permeability Versus Depth in the Upper Oceanic Crust' In Situ Measurements in DSDP Hole 504B, Eastern Equatorial Pacific" (1985). USGS Staff -- Published Research. 406.

https://digitalcommons.unl.edu/usgsstaffpub/406

This Article is brought to you for free and open access by the US Geological Survey at DigitalCommons@University of Nebraska - Lincoln. It has been accepted for inclusion in USGS Staff -- Published Research by an authorized administrator of DigitalCommons@University of Nebraska - Lincoln. 


\title{
Permeability Versus Depth in the Upper Oceanic Crust: In Situ Measurements in DSDP Hole 504B, Eastern Equatorial Pacific
}

\author{
ROGER N. ANDERSON \\ Borehole Research Group, Lamont-Doherty Geological Observatory, Columbia University \\ Palisades, New York \\ MARK D. ZOBACK ${ }^{1}$ AND STEPHEN H. HickMaN ${ }^{2}$ \\ U.S. Geological Survey, Menlo Park, California \\ Robin L. NEWMARK \\ Borehole Research Group, Lamont-Doherty Geological Observatory, Columbia University \\ Palisades, New York
}

\begin{abstract}
In situ permeabilities measured within the upper kilometer of oceanic crust in hole 504B on the south flank of the Costa Rica Rift decrease exponentially from $10^{-13}$ to $10^{-14} \mathrm{~m}^{2}$ in layer $2 \mathrm{~A}$ (the upper $150 \mathrm{~m}$ ) to $10^{-15}$ to $10^{-17} \mathrm{~m}^{2}$ in layer $2 \mathrm{~B}\left(150-550 \mathrm{~m}\right.$ into basement), and to $10^{-17} \mathrm{~m}^{2}$ and lower in layer $2 \mathrm{C}$ (deeper than $550 \mathrm{~m}$ ). We estimate the permeability $(k)$ versus depth $(z)$ to vary as $k(z)=0.11 e^{(-z / 50)}$ $\times 10^{-12} \mathrm{~m}^{2}$. If this permeability versus depth function is representative of the oceanic crust in general, then hydrothermal convection would be vertically stratified, with the most vigorous circulation confined to the shallowest pillow basalt layers of the crust. The use of a full suite of geophysical logs (including borehole televiewer imagery; multichannel, full waveform sonic; nuclear; and variable spacing electrical resistivity logs) allows the characterization of the scale and interconnectedness of fractures, and the degree of infilling of these fractures by alteration minerals. At hole 504B, we observe a relationship between permeability and fracture porosity, determined from the geophysical logs. If fractures with similar aspect ratios are encountered at other oceanic sites, then prediction of the permeability of the oceanic crust to within an order of magnitude is possible from geophysical logs. At hole $395 \mathrm{~A}$ in the Atlantic, for example, in situ permeability measurements yielded values similar to those predicted by the logging relationships established at hole 504B.
\end{abstract}

\section{INTRODUCTION}

Convection of seawater within the oceanic crust is now a well-established physical observation. From hot springs spewing forth $350^{\circ} \mathrm{C}$, mineral-laden "smoke" at the ridge axes [e.g., Macdonald and Luyendyk, 1981], to $50 \mathrm{Ma}$ seafloor in the Indian Ocean with the distinct heat flow "oscillations" characteristic of ridge flank convection [Anderson et al., 1979], to helium anomalies which are a fingerprint of convection in 20 Ma sediments of the eastern Pacific [Sayles and Jenkins, 1982], the evidence continues to accumulate that hydrothermal circulation is one of the dominant physical and chemical processes controlling aging of the oceanic crust. Fully one third of all seafloor is thought to have active convection within its crust, and the other two thirds bears the unmistakable chemical signature of past hydrothermal activity [e.g., Staudigal and Hart, 1984]. Yet the most fundamental physical parameter which controls the form, magnitude, and duration of ocean crustal convection is also the least well understood: permeability. We know neither about the permeability versus depth function in the oceanic crust, nor how it varies with age and geography.

\footnotetext{
1 Now at Department of Geological Sciences, Stanford University, California.

${ }^{2}$ Now at Department of Earth, Atmospheric, and Planetary Sciences, Massachusetts Institute of Technology, Cambridge.

Copyright 1985 by the American Geophysical Union.

Paper number 4B5046.

0148-0227/85/004B-5046\$05.00
}

In order to measure directly this crucial parameter, we have been conducting in situ flow tests in Deep Sea Drilling Project (DSDP) boreholes over the last 6 years: first in hole 504B in the eastern Pacific on legs 68 and 69 [Anderson and Zoback, 1982], then in hole 395A on the Mid-Atlantic Ridge during leg 78B [Hickman et al., 1984], and then again in hole 504B on legs 83 and 92 (reported below). Hole 504B has penetrated over $1 \mathrm{~km}$ into the upper oceanic crust and, as such, offers the first DSDP hole in which measurements of permeability have been made in layers $2 \mathrm{~A}, 2 \mathrm{~B}$, and $2 \mathrm{C}$ of the crust.

In this paper, we report permeability measurements made over the lower $750 \mathrm{~m}$ of hole 504B during leg 83, and we derive a permeability versus depth function from this and previous measurements made at this site. We then examine geophysical logs from the hole to determine if they may be used to predict permeability by indirect means. The crucial parameters that we extract from these logs are the scale of fracturing, how interconnected these fractures are, and how much the infilling of alteration minerals has clogged the fractures. As will be shown below, these logs offer great promise as a predictor of crustal permeability, at least to within an order of magnitude accuracy.

This extension from direct to indirect measurement of permeability is essential if we are to discuss premeability versus depth and age in the oceanic crust on a large scale. The experimental procedure involved in direct permeability measurement is much too complex, time consuming, and fraught with mechanical difficulty to be carried out extensively in the oceanic crust within the next several years. Geophysical logs are relatively cheap and easy to obtain, however. 


\section{THE EXPERIMENT}

Hole 504B (Figure 1) is currently the deepest penetration into oceanic crust, reaching $1050 \mathrm{~m}$ subbasement. The stratigraphic sequence encountered during drilling on legs 68,69 , 70,83 , and 92 was a rubbly, pillow basalt interval just below $300 \mathrm{~m}$ of carbonate sediments (with chert stringers near the bottom). This upper pillow basalt interval contains several massive basaltic flow units with thicknesses of the order of several meters. Despite the flow units, the upper $150 \mathrm{~m}$ were both highly permeable and underpressured, so that penetration of the relatively impermeable sedimentary lid during drilling resulted in drawdown of ocean bottom water into the formation [Anderson and Zoback, 1982; Becker et al., 1983]. The source of the underpressures is believed to be a hydrothermal convection system which is active within the oceanic crust in this $6.1 \mathrm{Ma}$ seafloor on the southern flank of the Costa Rica Rift (C. T. Williams et al., unpublished manuscript, 1984). Anderson et al. [1982] have classified this stratigraphic sequence as belonging to layer $2 \mathrm{~A}$.

Between $150-\mathrm{m}$ and $550-\mathrm{m}$ subbasement $(420 \mathrm{~m}$ and $820 \mathrm{~m}$ below seafloor), the pillow basalts become more altered and less "rubbly." This interval is thought to be layer $2 \mathrm{~B}$ of the oceanic crust. At the base of this layer, a transition zone of alternating pillow basalt and dike units is found. A metalliferous stockwork was also encountered within this zone. The lower $400 \mathrm{~m}$ of basement drilled in hole 504B consist of a sheeted dike complex, so that the overall geology agrees with an "ophiolite" model for the structure of the oceanic crust [Anderson et al., 1982].

During leg 69, we conducted "slug-type" permeability tests

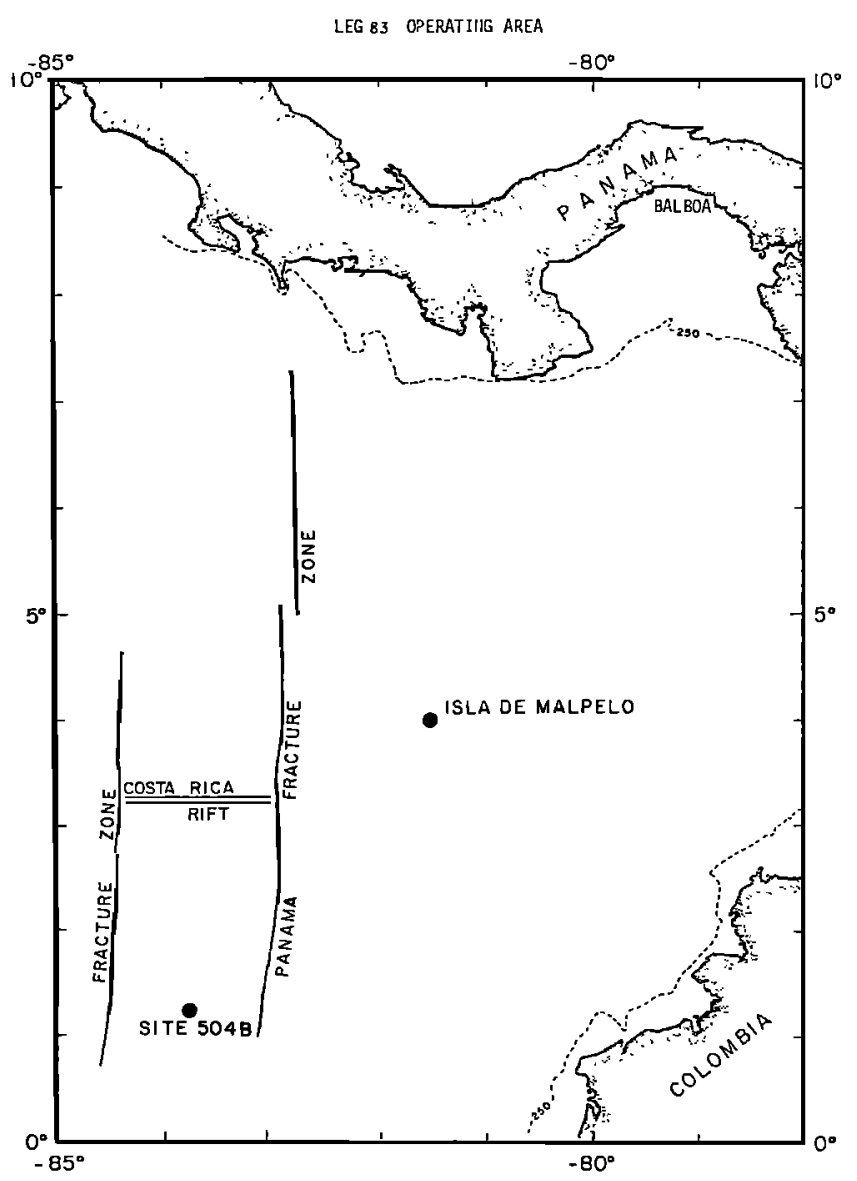

Fig. 1. Location of Deep Sea Drilling Project hole 504B. using an inflatable rubber packer to measure directly the decay of a pressure pulse forced first into layer $2 \mathrm{~A}$, then into the top of layer $2 \mathrm{~B}$. We measured bulk permeability values of $4 \times 10^{-14} \mathrm{~m}^{2}$ in the layer $2 \mathrm{~A}$ inverval of 50 - to $200-\mathrm{m}$ subbasement and $4 \times 10^{-15} \mathrm{~m}^{2}$ at 195 - to $210-\mathrm{m}$ subbasement, which is at the top of layer 2B [Anderson and Zoback, 1982].

In addition, the underpressures were measured and found to be 8-12 bars subhydrostatic within layer 2A [Anderson and Zoback, 1982]. This underpressure combined with flow rates into the "aquifer" calculated from depressed borehole temperatures allowed for the calculation of a bulk permeability of $7 \times 10^{-14} \mathrm{~m}^{2}$ for the upper $100 \mathrm{~m}$ of layer $2 \mathrm{~A}$ [Becker et al., $1983]$.

The drop in permeability of over an order of magnitude explains why the ocean bottom water drawn down into the crust flows into the layer $2 \mathrm{~A}$ aquifer but not into the deeper formations in the hole, and why temperatures deeper in the borehole are much higher than those in layer 2A (Figure 2). The higher temperatures are closer to those expected from a purely conductive geothermal gradient within the lower crust and would imply much lower permeability values for the oceanic crust below layer $2 \mathrm{~A}$ than was measured at the top of layer 2B [Becker et al., 1983].

\section{The Packer}

To test if permeability drops by several orders of magnitude within layer 2 at hole 504B, we attempted additional hydrological experiments over the lower two thirds of hole 504B. During leg 83, we were successful at setting a Lynes International During Drilling Safety Tool (DDST) rubber packer 749 $\mathrm{m}$ above the bottom of the hole and then forcing water (which we pumped down the drill pipe) into the formation. The packer and experimental procedure are described by Anderson and Zoback [1982], Hickman et al. [1984], and Anderson et al. [1984b].

The volume of water pumped into the formation is called a "slug" because the water pressure in the wellbore is raised almost instantaneously $\left(H_{0}\right)$. We then monitor the decay of this pressure slug $(H)$, and the rate of return to normal formation pressures is a direct measure of the formation permeability. This permeability is a "bulk" measurement over the entire interval between the bottom of the hole and the location of the packer.

The results of this test are described below. The slug test theory used to derive permeability from pressure-time measurements is detailed in the appendix and in the work of Hickman et al. [1984]. Constant flow rate and drawdown tests which failed on legs 83 and 92 are described by Anderson et al. [1984b].

\section{The Slug Test Results}

For the successful slug test, the packer element was set across a massive flow unit seen on the borehole televiewer log [Newmark et al., 1984] at $4010 \mathrm{~m}$ below the rig floor $(524 \mathrm{~m}$ below the seafloor and $250 \mathrm{~m}$ into basement). Three consecutive slugs were injected into the formation: the first began at 12.5 bars above hydrostatic and was monitored for $730 \mathrm{~s}$, the second began at 15.5 bars above hydrostatic and was recorded for $734 \mathrm{~s}$, and the third began at 14.6 bars for $717 \mathrm{~s}$ (Figure 3).

The $H / H_{0}$ versus time plots from the slug test over the lower $749 \mathrm{~m}$ of hole 504B agree well with curve shapes predicted by Cooper et al. [1967] (Figure 4). For the permeability calculation of Appendix equation (A3), the volume of water pressurized $\left(7.8 \times 10^{+7} \mathrm{~cm}^{3}\right)$ is the length of drill pipe from 


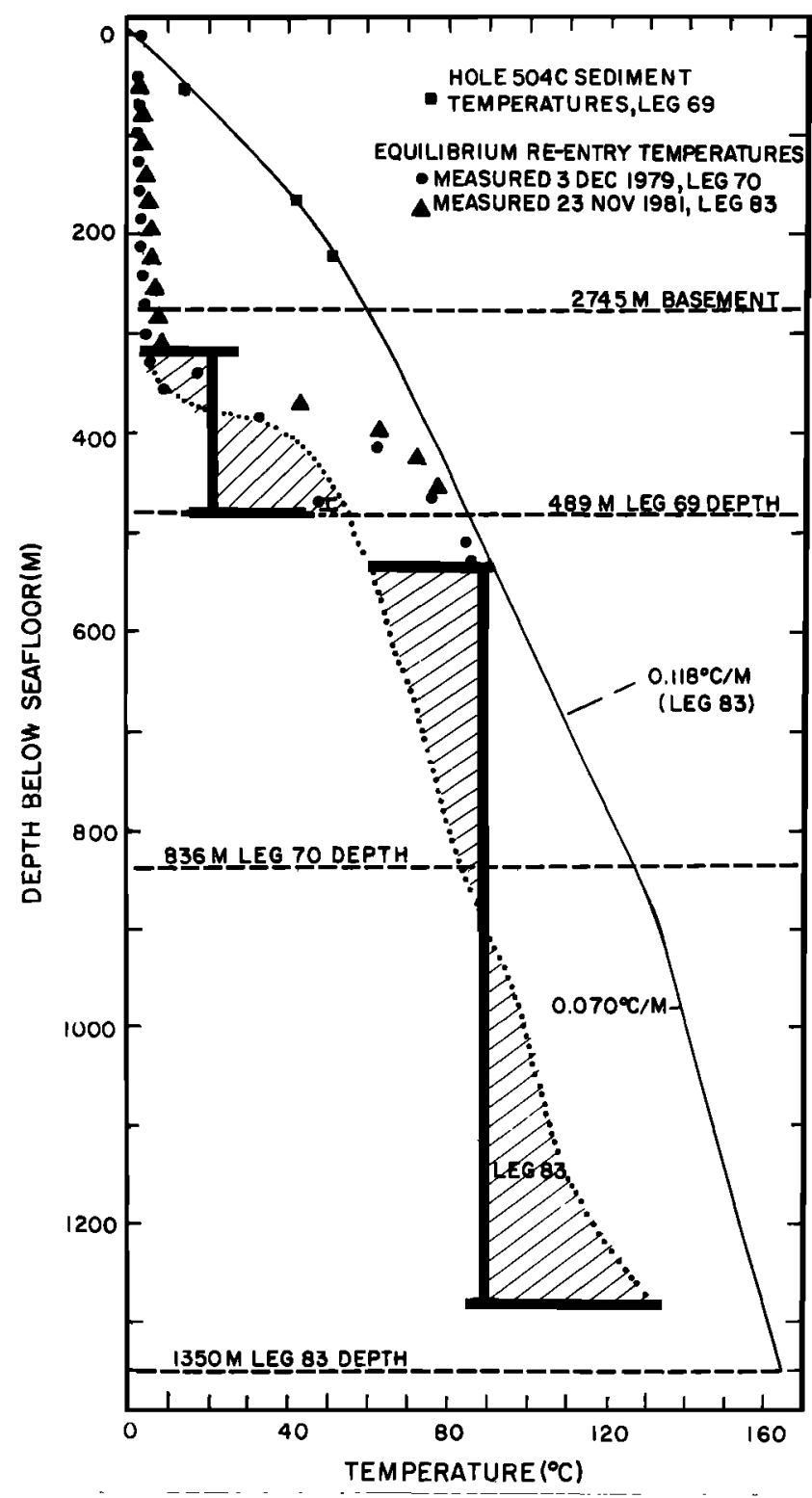

Fig. 2. Temperatures measured 26 hours after circulation in hole 504B (dotted line), and calculated equilibrium formation temperatures (solid line). See Becker et al. [1983] for details. The permeability test reported in this paper was over the lower $749 \mathrm{~m}$ of the hole (bottom hatched interval). We estimate that the average temperature of borehole water injected into the formation during that test was $90 \pm 30^{\circ} \mathrm{C}$ The tests from Anderson and Zoback [1982] are also shown in this figure (upper hatched interval just below sediment-basement interface).

the surface to the drill bit $3 \mathrm{~m}$ below the packer times the interval cross-sectional area of the pipe, plus the length of open hole beneath the drill bit times the area of the open hole. Density and compressibility values for water at the hole 504B test depth are taken as in the work of Hickman et al. [1984].

There are two contributions to error with which we are particularly concerned. First, error in fitting the proper alpha curve is estimated as discussed in the appendix by "misfitting" the data with alpha curves one order of magnitude larger and smaller than the best fit for each test. Transmissivity values together with these errors are given in Table 1.

A second source of error arises because we do not have a firm idea what the temperatures are for the fluid injected into the test interval, and viscosity is strongly temperature depen- dent. The time between last circulation of the entire well and setting of the packer will determine the amount of reheating of the wellbore fluid as it rebounds to the formation equilibrium temperature. It is then this wellbore fluid which is pumped into the formation. For this permeability test, the drill string was pulled completely to the surface after the last circulation, and the packer was attached and run back into the hole. The amount of time elapsed was 26 hours. A reasonable estimate of the temperature of water in the well after that time comes from temperature logs run after similar delays during the logging program (Figure 2).

We calculate the temperature $(T)$ dependent viscosity, as $0.1668 T^{-0.8987}$ in poise [Gartling, 1977; Gartling and Hickox, 1979]. The likely average fluid temperature within the test interval is $90^{\circ} \mathrm{C}$ (Figure 2). We estimate error introduced into the permeability calculation from uncertainty in temperature by calculating $k$ using viscosities at $60^{\circ}$ and $120^{\circ} \mathrm{C}$. The latter is a likely maximum because it is the average formation temperature, itself, and the former is the estimated temperature of water at the top of the test interval. We then combined the error introduced by uncertainties in temperature with errors introduced by possible mismatches to the type curve (in such a way as to maximize the composite error) to produce the permeabilities in Table 1.

We calculate a composite permeability value for the lower $749 \mathrm{~m}$ of hole $504 \mathrm{~B}$ to be $1.4 \times 10^{-17} \mathrm{~m}^{2}$, from the average of all values calculated in Table 1 .

Because Anderson and Zoback [1982] completed the permeability tests in the shallow portion of the hole before the lower $800 \mathrm{~m}$ were drilled, they were unaware of the rapid temperature increase below the aquifer in layer $2 \mathrm{~A}$. They then used viscosity for $20^{\circ} \mathrm{C}$ water for all their calculations. While this is a reasonable value for the constant-rate flow test from 50 to $200 \mathrm{~m}$ into basement (see Figure 2), the two slug tests at 190 to $210 \mathrm{~m}$ injected waters hotter than these into the formation. We recalculate these latter permeability values using water temperatures of $50^{\circ} \mathrm{C}$ and find the permeability to be $2.6 \times 10^{-15} \mathrm{~m}^{2}$ and $1.9 \times 10^{-15} \mathrm{~m}^{2}$, respectively.

\section{Discussion}

The successful packer seat during leg 83 gave good results; the curve fits were excellent for all three slug tests conducted over the lower $749 \mathrm{~m}$ of the hole, and the error estimates for each test overlap those for the others. The primary cause for error, i.e., unknown temperatures of injected fluid, will be difficult to reduce in future testing because even if a temperature sensor is included with the downhole pressure gauge, the temperature profile below the packer will still be indeterminate.

The most important result of the hydrological measurements in hole 504B is the drop in bulk permeability from approximately $10^{-13}$ to $10^{-14} \mathrm{~m}^{2}$ in layer $2 \mathrm{~A}$ to $10^{-15} \mathrm{~m}^{2}$ at the top of layer $2 \mathrm{~B}$ to $10^{-17} \mathrm{~m}^{2}$ over layers $2 \mathrm{~B}$ and $2 \mathrm{C}$ (Figure 5). Extrapolation of the observed decrease into layer 3 would predict gabbroic permeability to be less than $10^{-19} \mathrm{~m}^{2}$. Essentially impermeable granites have such permeabilities. Such an extrapolation is unwarranted at this time because, to our knowledge, few in situ measurements of permeability in gabbros of any kind have ever been made. Also, the major drinking water supply on Cyprus is from the gabbroic layers of the Troodos ophiolite, widely held to represent ancient seafloor. This implies high present-day permeability for layer 3 of the Troodos ophiolite (because of extensive fracturing either before or after emplacement?) and might prevent further speculation about the extrapolation of our results into layer 3. 


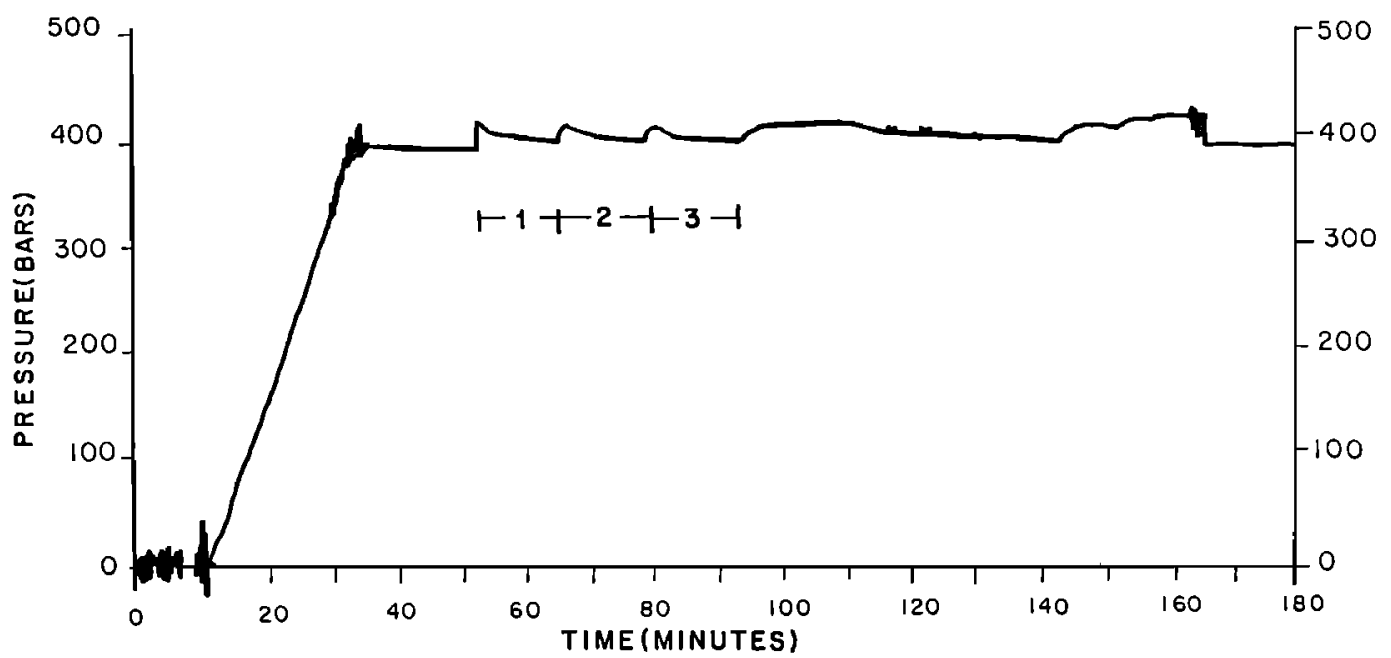

Fig. 3. Pressure versus time record from the Kuster pressure gauge mounted below the packer within the test interval for the permeability measurement over the lower $749 \mathrm{~m}$ of hole $504 \mathrm{~B}$. The numbers 1,2 , and 3 indicate the pulse numbers in Table 1. After pulse 3, a constant-rate injection test was attempted but the packer seal failed. The stylus reached the end of the record before the gauge returned to the surface, explaining why pressure did not return to atmospheric.

We can estimate the decrease in permeability versus depth by curve fitting to the measurements in hole 504B. Because of the large depth intervals over which most of the measurements were made, such a curve is "pinned" only at the 190- to $210-\mathrm{m}$ subbasement measurement point. However, an average rate of decrease of permeability with depth can be calculated from a least squares fit to the permeability at the top of each measurement interval. This assumption implies, in effect, that permeability decreases exponentially with depth and that most fluid injected into the large test intervals permeates into the top of the interval. Keeping in mind these strong assumptions, the following relation results (Figure 5):

$$
k(z)=0.11 e^{(-z / 50)} \times 10^{-12} \mathrm{~m}^{2}
$$

This equation probably results in a permeability estimate accurate to an order of magnitude in hole 504B. The quality of the relation would be improved greatly with another point as deep as possible in the hole. Another drill ship will perhaps occupy hole 504B in 1986 as part of the next phase of ocean drilling. Such a permeability experiment should be of the highest priority.

Although we have no idea at this time how representative hole 504B is of the rest of the worldwide oceanic crust, we can compare these first permeability versus depth measurements with functions used in theoretical models for convection in the oceanic crust. Three "guesses" used in theoretical models are displayed against the measurements in hole 504B in Figure 5. Number one is from Ribando et al. [1976], number two is from D. K. Gartling and R. N. Anderson (unpublished manuscript, 1984), and number three represents two different models presented by Fehn et al. [1983]. All have significantly underestimated permeability in layer $2 A$ and overestimated permeability in layers $2 B$ and $2 C$.

Use of our experimentally derived $k(z)$ function within their models would produce more vigorous shallow circulation within the pillow basalts of layer $2 \mathrm{~A}$ and more sluggish flow within the sheeted dikes of layer $2 \mathrm{C}$ (C. T. Williams et al., unpublished manuscript, 1984). Such highly stratified hydrothermal circulation places important constraints on the alteration history of the oceanic crust. The water-rock ratio must drop exponentially with depth to mirror the per- meability versus depth function into the crust. The chemical exchange caused by the lower water-rock ratios and the resultant higher temperatures in layers $2 \mathrm{~B}$ and $2 \mathrm{C}$ must be considerably different from that in the cold, open geochemical system active in layer $2 \mathrm{~A}$. Again referring to Troodos, the major ore deposition sites appear to be somewhere within layer $2 \mathrm{~B}$, and certainly between the layer $2 \mathrm{~A}$ pillow basalts and the layer $2 \mathrm{C}$ dikes. The rapid change in permeability across these layers might account for this deposition, since cold ocean bottom waters convecting through layer $2 \mathrm{~A}$ would meet hot, metalrich waters from layer $2 \mathrm{C}$ at this boundary. This same locale is where the mineralized stock work was found during the drilling of DSDP hole 504B [Anderson et al., 1982].

Another important unknown in the permeability versus depth function is the time term. We have little evidence with which to add age dependence to the hole 504B results, let alone to a general relationship. The alteration of the minerals found in cores from layer $2 \mathrm{C}$ shows clear indications of a previous, higher-temperature history, followed by much colder conditions than those currently found in the hole [Alt and Laverne, 1984]. Both colder and hotter circulation systems imply that the permeability in layer $2 \mathrm{C}$ was higher, and the circulation was more vigorous in the past than at present. That is, high temperatures were probably present right at the ridge axis when mineralization responsible for the stock work at the dike-pillow boundary was formed. As mentioned above, cold waters circulating downward through the highly permeable layer $2 \mathrm{~A}$ are required to have met hot, mineralized waters from layer $2 \mathrm{C}$ to account for the deposition of metalrich veins at that time. The colder circulation phase is seen on all ridge flanks as lower than expected surface heat flow [ $A n-$ derson et al., 1977]. High permeabilities are required in the past to have cooled the dikes to temperatures lower than those encountered at present.

The reheating of layer $2 \mathrm{C}$ could result either from sealing of the circulation system at the sediment-basement interface by the formation of chert and/or from an abrupt drop in bulk permeability caused by the precipitation of alteration minerals within the fracture system in the dikes [Anderson and Zoback, 1982]. These two explanations are not mutually exclusive, since sealing from above would cause hydrothermal fluids to 


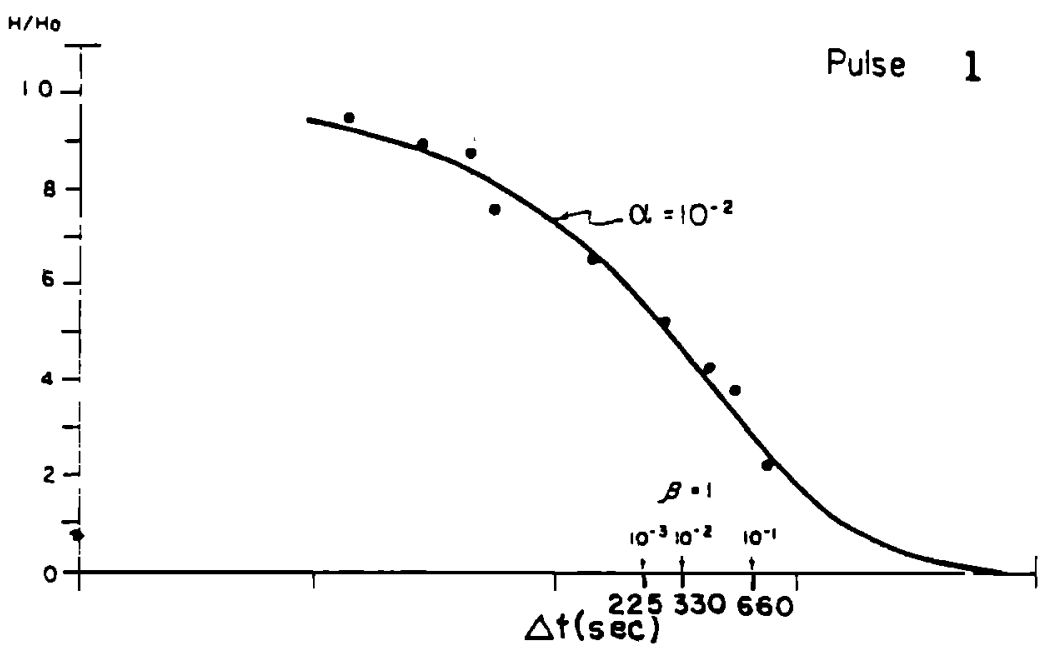

Pulse 2

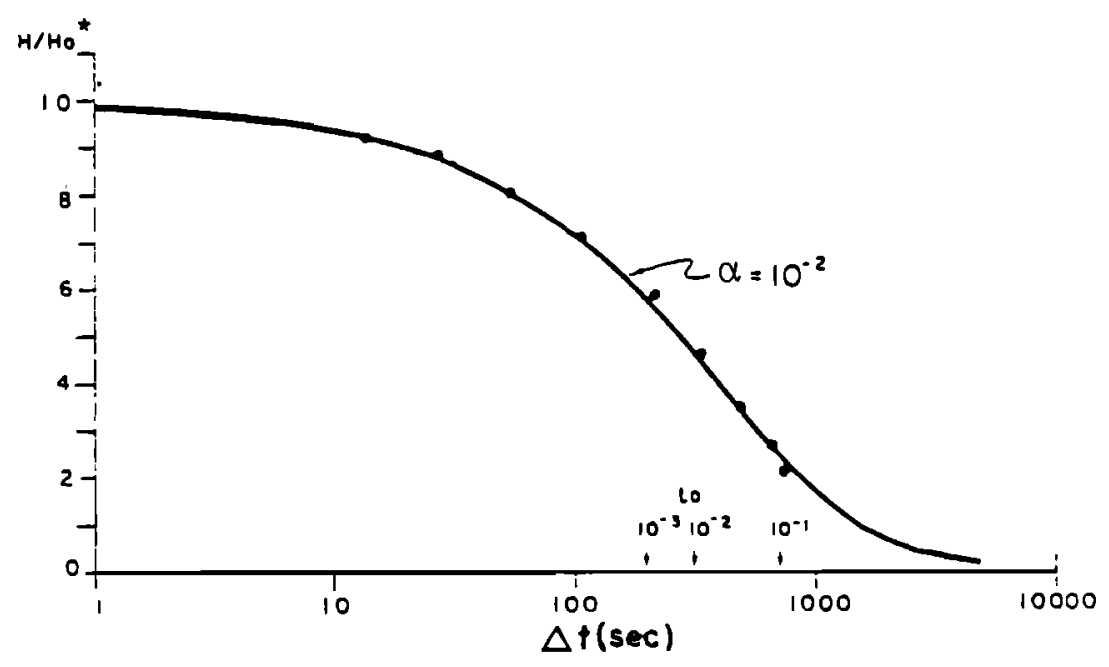

Pulse 3

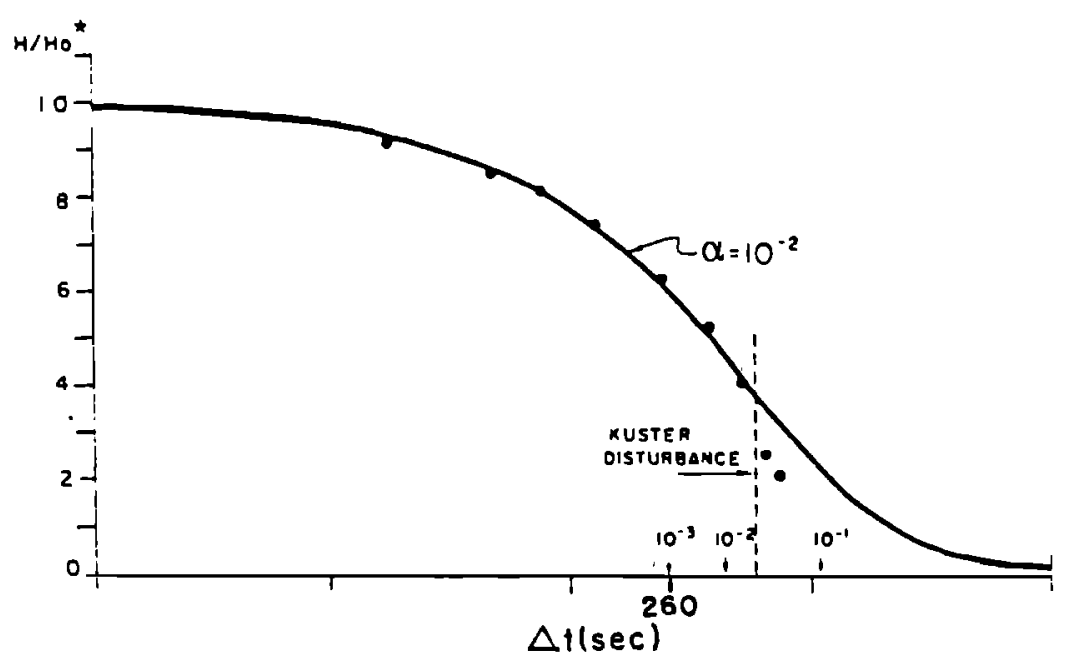

Fig. 4. Pressure versus time curves for pulses 1-3 of Figure 3 for permeability measurements over the lower $749 \mathrm{~m}$ of hole 504B. Curves are from Cooper et al. [1967]. Arrows indicate $t_{0}$ values for fits to various alpha curves. $H / H_{0}{ }^{*}$ indicates correction made for datum shift from residual of last pulse (see appendix). Errors from reading the pressure-time record using the Kuster uphole microscope are estimated to be less than the size of the dots in this figure. 
TABLE 1. Hole 504B Permeability Calculation at 4010-m Packer Depth, $749 \mathrm{~m}$ Above Total Depth

\begin{tabular}{|c|c|c|c|c|c|}
\hline $\begin{array}{l}\text { Pulse } \\
\text { No. }\end{array}$ & $\begin{array}{c}y \\
\text { (Alpha } \\
\left.\times 10^{y}\right)\end{array}$ & $\begin{array}{l}t, \\
\mathrm{~s}\end{array}$ & $\underset{\mathrm{cm}^{2} / \mathrm{s}}{T}$ & $\begin{array}{c}\text { Average } \\
\text { Temperature, } \\
{ }^{\circ} \mathrm{C}\end{array}$ & $\begin{array}{c}k, \\
\times 10^{-17} \mathrm{~m}^{2}\end{array}$ \\
\hline \multirow[t]{3}{*}{1} & -2 & 330 & 3.25 & 90 & 1.2 \\
\hline & -1 & 225 & 4.78 & 60 & 2.6 \\
\hline & -3 & 660 & 1.63 & 120 & 0.5 \\
\hline \multirow[t]{3}{*}{2} & -2 & 300 & 3.6 & 90 & 1.4 \\
\hline & -1 & 200 & 5.3 & 60 & 2.9 \\
\hline & -3 & 700 & 1.5 & 120 & 0.4 \\
\hline \multirow[t]{3}{*}{3} & -2 & 450 & 2.4 & 90 & 0.9 \\
\hline & -1 & 260 & 4.1 & 60 & 2.3 \\
\hline & -3 & 1050 & 1.02 & 120 & 0.3 \\
\hline
\end{tabular}

recirculate several times within a closed system. Temperature and mineral precipitation would both be enhanced in such a closed geochemical system.

\section{Qualitative Estimates of Permeability USING GEOPHYSICAL LOGS}

It is necessary to speculate about ways to derive permeability from other means than by flow tests because the likelihood of ever accumulating enough experimental data from packer experiments during deep-sea drilling is small. The most likely data set from which to derive permeability information is geophysical logging. In situ logging measurements of the absorption characteristics of the formation to neutron and gamma ray bombardment reveal locations and concentrations of alteration minerals and free water porosity [ $\mathrm{An}$ - derson et al., 1984a]. Electrical resistivity source-receiver logs of differing array lengths map the porosity of the crust over distances away from the wellbore ranging from a few centimeters to tens of meters [Becker et al., 1982]. Full waveform logging of sonic energy at multiple receivers provides a mechanism for determining the "acoustic permeability" of the formation and for estimating the average length and width of interconnected fractures responsible for energy loss into the formation [Anderson et al., 1984a]. Ultrasonic borehole logging provides visual imaging of fracture size and distribution [Zoback and Anderson, 1982]. A mechanism must be developed for integrating these geophysical logging results with regional geophysical surveys and core observations to provide a framework for estimating permeability in the crust.

The first problem has to do with scales of fracturing. Surface seismic refraction experiments determine velocities from sound sources of $10-$ to $100-\mathrm{Hz}$ frequency. Velocities from sonic logging are determined from source frequencies of about $10 \mathrm{kHz}$, and laboratory measurements of velocity come from transmission of ultrasonic frequency sound. The intercomparison of the velocities from these three different experiments gives some idea of the predominance of fractures appropriate to the wavelengths of each measurement. If logging velocities are similar to surface refraction velocities, as is the case at hole 504B [Newmark et al., 1984; R. A. Stephen and A. J. Harding, unpublished manuscript, 1984], then fractures of less than 1-m length must form an interconnected framework that extends several hundred meters away from the borehole in order for velocities from energies of such disparate wavelengths to be similar. If velocities from laboratory measurements on cores

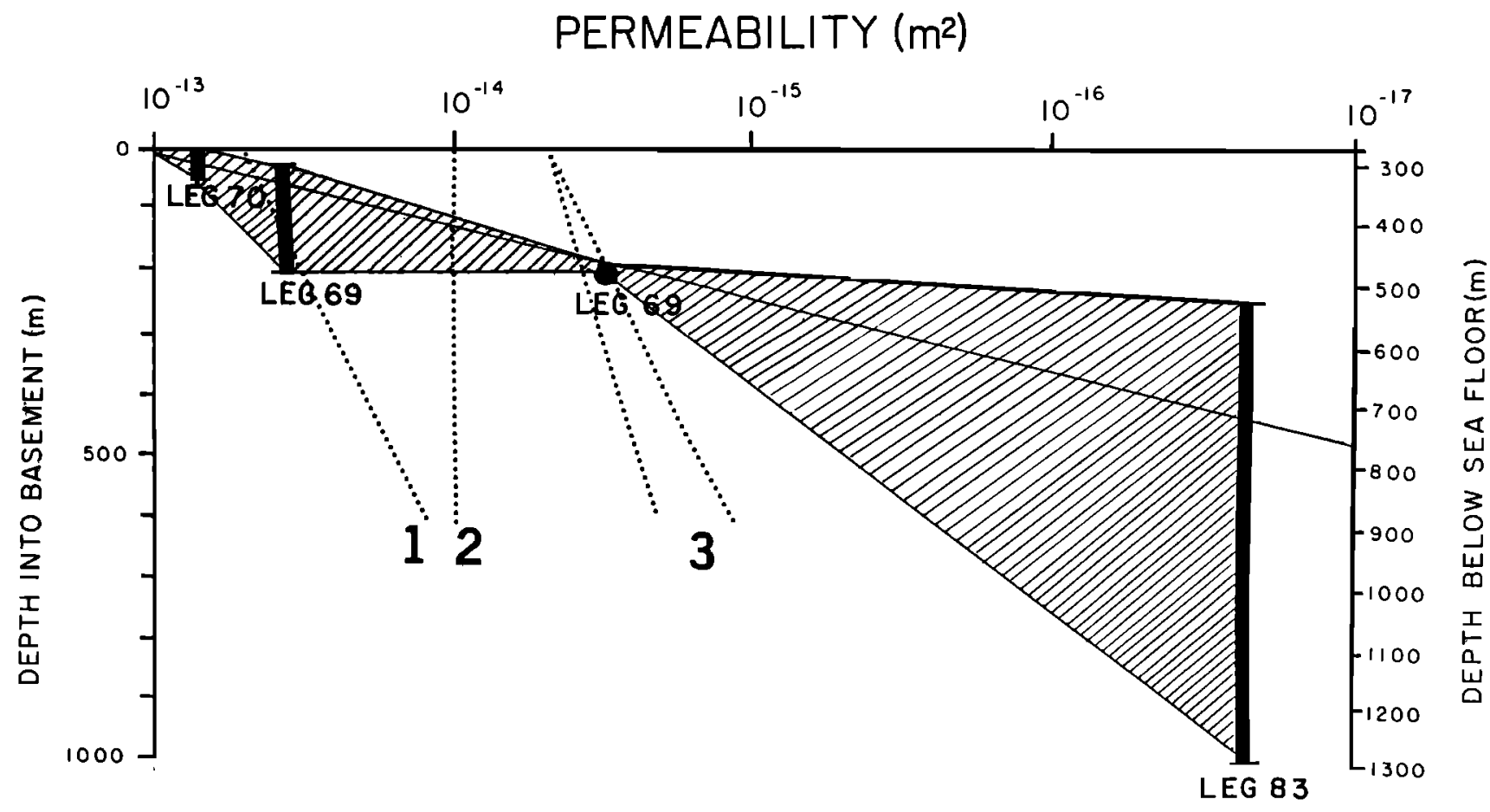

PERMEABILITY/DEPTH FUNCTION

Fig. 5. All measurements of permeability from hole 504B from this paper, Anderson and Zoback [1982], and Becker et al. [1983], plotted versus depth. Shading indicates uncertainty in permeability versus depth function caused by widths of the various intervals over which permeability was measured. Numbers refer to guesses of this function from (1) Ribando et al. [1976], (2) D. K. Gartling and R. N. Anderson (unpublished manuscript, 1984), and (3) two models from Fehn et al. [1983]. The light solid line is least squares curve fit to permeability values at the shallowest depth of each test (equation given in text). 

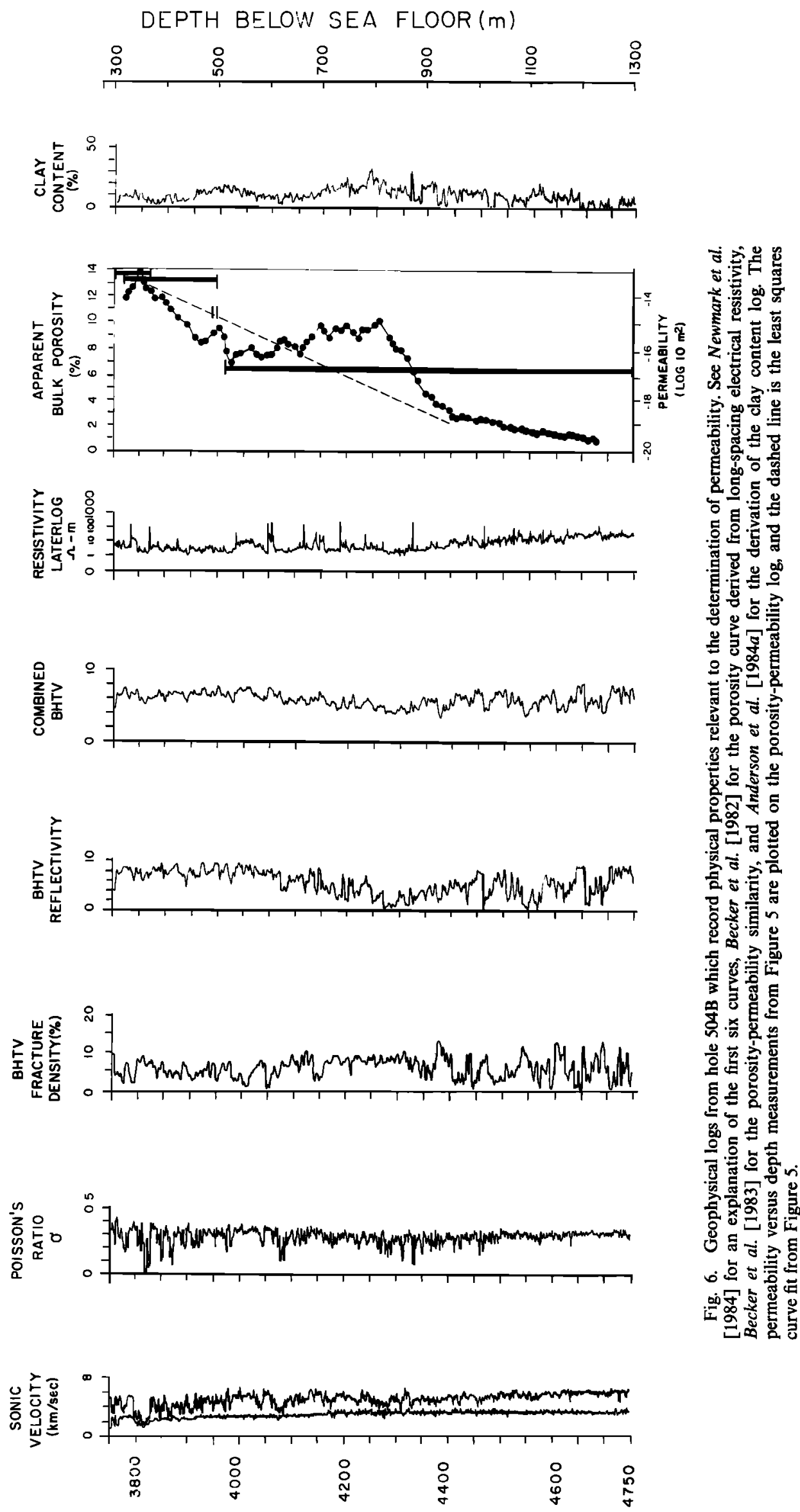

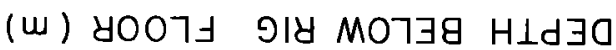




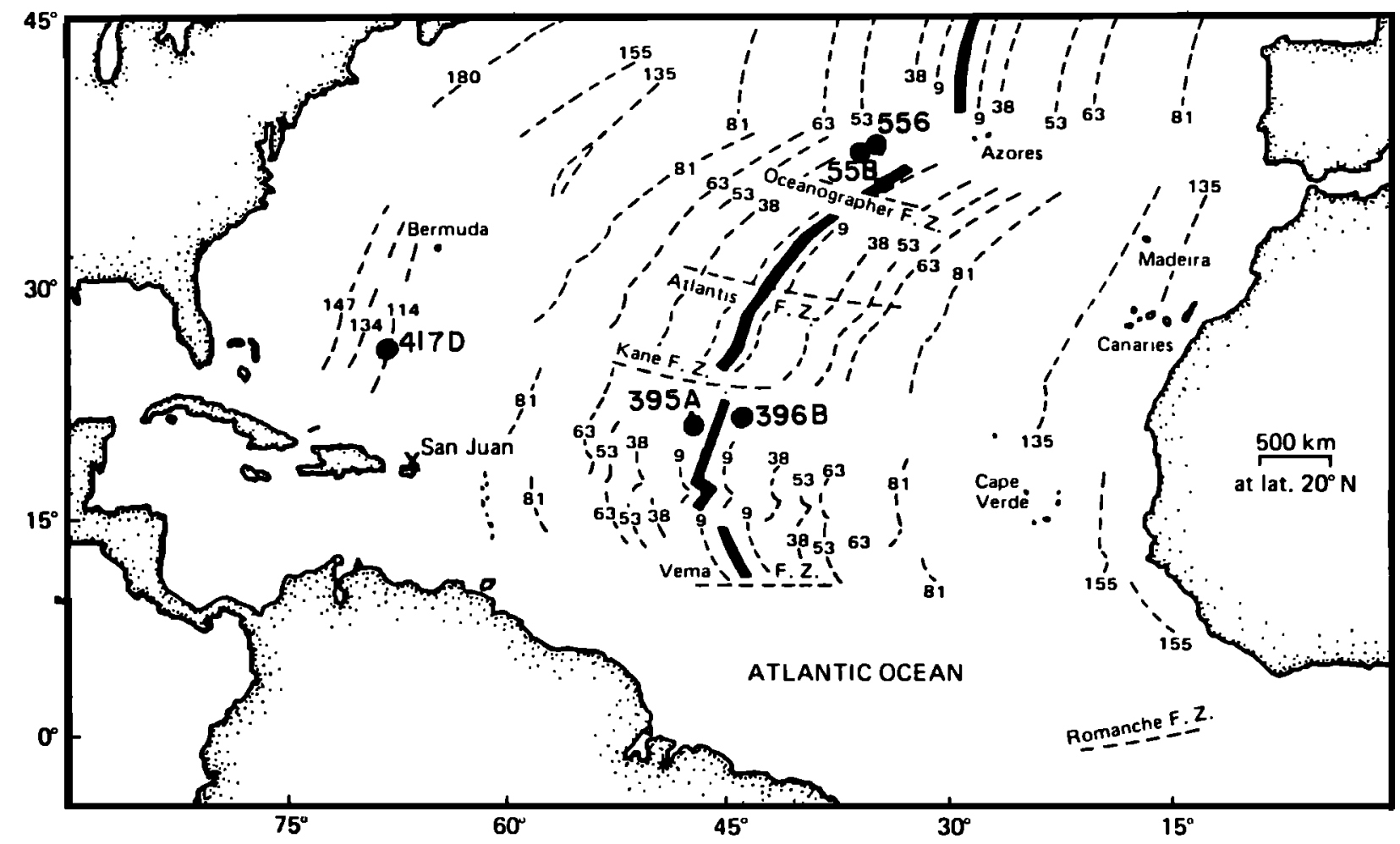

Fig. 7. Location map for the DSDP holes from the Atlantic used in Figure 8, from Hickman et al. [1984]. Hole locations are $396 \mathrm{~B}\left(23.05^{\circ} \mathrm{N}, 43.30^{\circ} \mathrm{W}\right), 417 \mathrm{D}\left(25.04^{\circ} \mathrm{N}, 68.05^{\circ} \mathrm{W}\right), 395 \mathrm{~A}\left(22.45^{\circ} \mathrm{N}, 46.05^{\circ} \mathrm{W}\right), 556\left(38.56^{\circ} \mathrm{N}, 34.41^{\circ} \mathrm{W}\right)$, and $558\left(37.46^{\circ} \mathrm{N}, 37.21^{\circ} \mathrm{W}\right)$. Numbers on dashed lines are laterolog age isochrons from magnetic anomaly identification.

are also too high to be consistent with either sonic logging or refraction results, again as is the case at hole 504B, then fractures not sampled within the cores must control the propagation of sound in the oceanic crust at least at hole 504B. That is, small fractures are required to slow velocities at the short wavelengths of the sonic log, but these fractures must be uniform over a large area to slow the velocities at the long wavelengths of the seismic survey.

In fact, the velocity results from hole 504B hold in general for fractured crystalline rocks. For example, Moos and Zoback [1983] found that logging velocities were consistent with refraction velocities but considerably lower than laboratory measurements of velocities on cores of granite from a Mojave Desert wellbore. It appears that the propagation of sound in crystalline media is controlled by interconnected macrofractures of the order of $1 \mathrm{~m}$ in length and millimeters to centimeters in aperture [Moos and Zoback, 1983; Seeburger and Zoback, 1982]. We are left, then, with the determination of the hydraulic permeability of these fractures.

For this, some measure of the porosity of the rock is needed. Just as with the acoustic experiments, electrical resistivity measurements at several different wavelengths can be used to estimate the scale of porosity. At hole 504B, the porosity determined from long-spacing resistivity measurements over tens of meters of the borehole agrees well with porosities calculated from the spherically focused laterolog, a device which penetrates only a few tens of centimeters into the formation [see Becker et al., 1982].

But additional tests need to be applied to the porosity calculation from resistivity logging to determine if it is due to fractures, and if so, whether those fractures are indeed open to hydraulic flow. For this, we use the borehole televiewer to produce an image of the wellbore [Zoback and Anderson, 1982]. A fracture log derived from the borehole televiewer [Newmark et al., 1984] can be compared to the porosity curves (Figure 6). If they track each other down the hole, then it is likely that the porosity resides within fractures in the rock.

Consider the borehole televiewer fracture density and resistivity logs of Figure 6. Both decrease from layer $2 \mathrm{~A}$ to reach a minimum at the top of layer $2 B$. They then increase into layer $2 \mathrm{~B}$, only to then drop to another minimum at the top of layer 2C. What little porosity present in the dikes most likely resides in the fractures still seen in abundance in the televiewer fracture $\log$ (Figure 6).

The nuclear logs provide a final piece of information crucial to the correlation between fracture porosity and permeability. The variation in alteration minerals, or "clay content," from the nuclear log cross correlation of neutron porosity versus gamma-ray porosity [Anderson et al., 1984a] will indicate the extent to which fractures are filled with alteration minerals when compared with the borehole televiewer fracture log and the porosity $\log$ determined from the electrical resistivity log. For example, porosity and fracture count are high in layer $2 \mathrm{~A}$, but the alteration log indicates fewer clay minerals are present than in layer 2B (Figure 6). High permeability could be expected in this zone, as is the case. Layer $2 \mathrm{~B}$ has lower permeability, as the combined analysis of the logs would predict. The porosity drops in layer $2 \mathbf{B}$; the fracture count first decreases, then increases; but the clay content increases substantially (Figure 6), indicating that fractures are clogged more completely with alteration products in layer $2 \mathrm{~B}$ than in layer $2 \mathrm{~A}$. The precipitous drop in permeability in layer $2 \mathrm{C}$ can also be predicted from the logs; the porosity drops significantly, 
the fracture count drops somewhat, and the clay content remains relatively high (see Figure 6 for quantitative estimates of these changes).

\section{Prediction of Permeability in Other DSDP BOREHOLES}

Becker et al. [1983] plotted permeability on the same graph as porosity derived from their long-spacing electrical resistivity experiment and suggested that the two were directly related. We have expanded the correlation at hole 504B to include other geophysical logs. But can reasonable predictions be made at other sites where permeability measurements have not yet been made?

We begin in the only other hole where in situ permeability measurements have been made in the oceans, hole 395A just off the axis of the Mid-Atlantic Ridge (Figure 7). Hickman et al. [1984] measured permeability values of 3 to $9 \times 10^{-18} \mathrm{~m}^{2}$ at 490 - to $571-\mathrm{m}$ subbasement, and they estimate values several orders of magnitude higher in the shallow crust at that site, based upon drawdown of ocean bottom water into an underpressured layer 2A. Although the geophysical logging results were of much poorer quality in hole $395 \mathrm{~A}$ than at hole 504B, a reasonably accurate electrical resistivity log was obtained (Figure 8). Here, as at hole 504B, we see low apparent resistivity where high permeability is suspected, and a dramatic increase in resistivity to values indicative of very low porosities at the bottom of the hole where low permeability was measured (Figure 8). In fact, the resistivity is higher than at hole 504B (after taking into account the higher temperature in hole 504B; see below) just as the permeability is lower, although some of this difference is caused by the difference in borehole temperatures between the two wells.

The conversion from electrical resistivity to porosity is strongly temperature dependent [cf. Von Herzen et al., 1983], and therefore good temperature versus depth information is required in a geothermally hot borehole such as hole 504B. All of the Atlantic boreholes referred to in this paper, however, are cold throughout, so an intercomparison of resistivities between the Atlantic holes is an accurate measure of porosity variations (Figure $8 b$ ). Increased temperatures decrease electrical resistivity, so hole 504B resistivities are lower than if normalized to a cold "Atlantic standard" (Figure $8 a$ versus Figure $8 b$ ). We then predicted premeability in the Atlantic boreholes from uncorrected electrical resistivity logging results instead of from calculated porosities as at hole 504B (Figure $8 b$ ). The permeability predicted in this manner is roughly consistent with that at the bottom of hole 395A measured by Hickman et al. [1984].

In order to have much faith in predictions of permeability based upon resistivity logging, other logs such as nuclear, sonic, and borehole televiewer should be available, but there are no other holes in the oceans at this time where such a geophysical logging program has been successfully carried out. In fact, there are only four other boreholes, holes 396B, 417D, 556, and 558, all in the Atlantic for which reliable electrical resistivity logs exist in the oceanic crust. These show resistivities consistent with permeability values measured at the two holes in which experiments have been carried out (Figure $8 b$ ). They predict permeability in the shallow Atlantic Ocean crust to be closer to that measured in layers $2 \mathrm{~A}$ and $2 \mathrm{~B}$ at hole 504B and inferred for the shallow crust at hole 395A, rather than the lower values measured at the bottom of both holes.

\section{SUMMARY}

Hickman et al. [1984] concluded that if the 3 to $9 \times 10^{-18}$ $\mathrm{m}^{2}$ permeabilities measured at the bottom of site $395 \mathrm{~A}$ are pervasive, this would strongly inhibit the vertical extent of convective heat transfer in the oceanic crust. We see that the permeability at $490-571 \mathrm{~m}$ into basement in hole $395 \mathrm{~A}$ is slightly less than that measured from 250 - to $999-\mathrm{m}$ subbasement at hole 504B (Figure 8). However, both measurements indicate permeabilities of approximately the same magnitude and imply that hydrothermal circulation might be strongly inhibited in the deeper oceanic crust at either site.

The other Atlantic holes examined (Figure 8), including site 396B in similar-aged seafloor (Figure 7), all predict permeabilities of $10^{-16} \mathrm{~m}^{2}$ or higher in layers $2 \mathrm{~A}$ and $2 \mathrm{~B}$, so the electrical resistivity-permeability analogy would strengthen

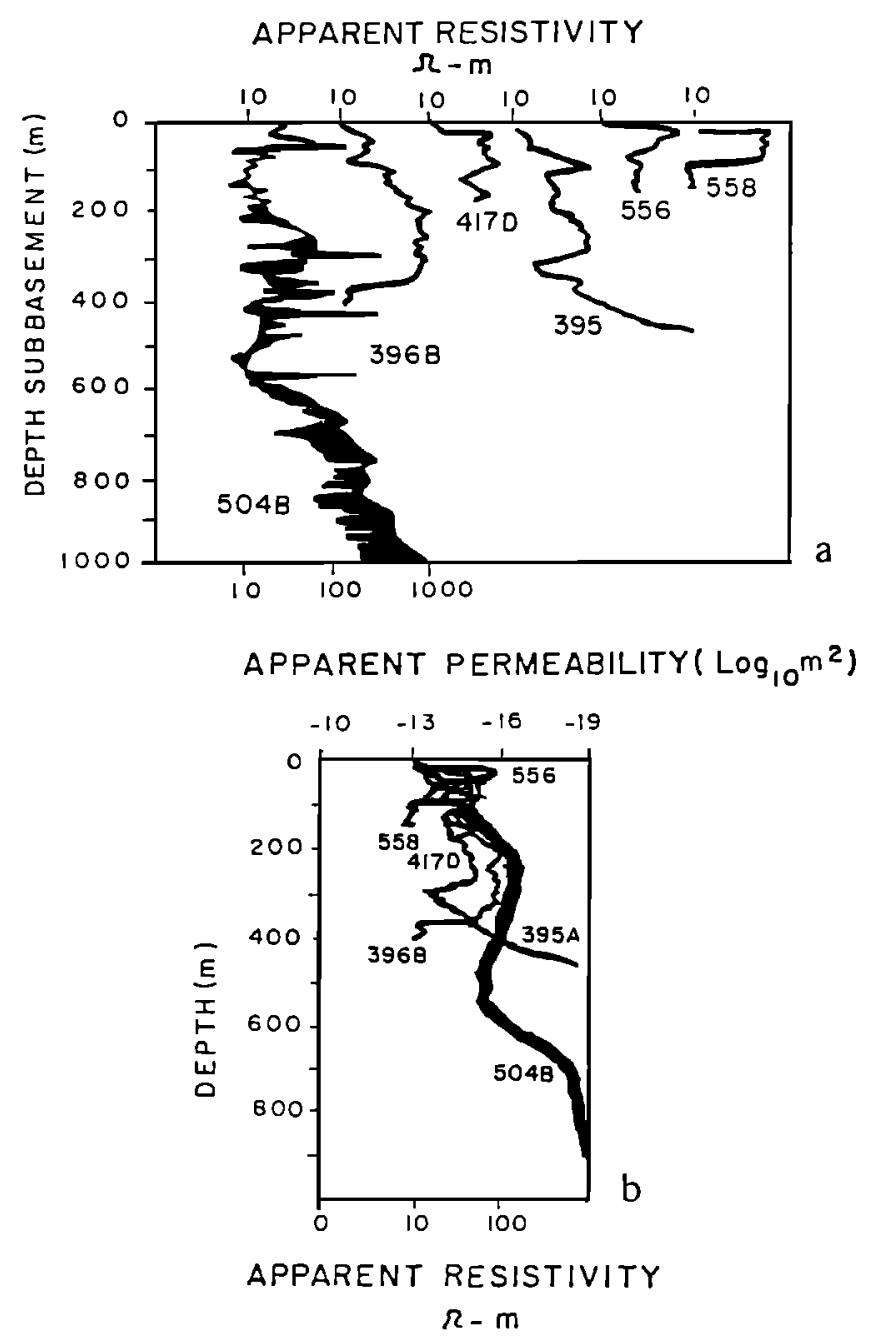

Fig. 8. (a) Apparent resistivities from laterologs run in DSDP holes located in Figure 7, together with resistivity from hole 504B. Shading in 504B log is difference between long-spacing $(10 \mathrm{~m})$ electrical resistivity log from Becker et al. [1982] (left) and spherically focused later log shown in Figure 6. (b) Apparent permeability and resistivity versus depth from relation derived by Becker et al. [1983] and shown in Figure 6. Temperature correction to electrical resistivity $\log$ at $504 \mathrm{~B}$ in Figure $8 a$ results in solid curve in Figure $8 b$. The Atlantic logs are all from cold boreholes, and so no temperature correction is required. Predicted permeabilities at holes 556, 558, $417 \mathrm{D}$, and $396 \mathrm{~B}$ are $10^{-13}$ to $10^{-16} \mathrm{~m}^{2}$. The extremely low permeability predicted at the bottom of hole 395A by the resistivity log was indeed measured in the hole by Hickman et al. [1984]. 
the argument for the high permeability of the shallow oceanic crust.

We have developed a conceptual analogy for extending the difficult and time-consuming task of measuring oceanic crustal permeabilities in situ to the more readily accessible "fracture porosity" determination using electrical resistivity and other geophysical logs. An internally consistent cross correlation among the extensive suite of in situ geophysical experiments at site 504B demonstrated that permeability in layer 2 basalts is controlled by fracture density and the degree of infilling of those fractures by alteration products. "Fracture porosity" derived from the electrical resistivity logs directly measures these changes downhole, and thus, at least in this hole, can be used to predict permeability. We tested this hypothesis at the only other ocean crustal site where electrical resistivity and in situ permeability were both measured, and we found that it predicts the extremely low permeabilities measured at 490- to 570-m subbasement depth at Mid-Atlantic Ridge site 395A.

We applied the predicted permeability versus depth variation in the shallow crust at four other Mid-Atlantic Ridge sites. They all suggest values of $10^{-13}$ to $10^{-16} \mathrm{~m}^{2}$ for the upper part of layer 2 . We do not yet have enough high-quality electrical resistivity logging results to test the variation with age of permeability (or even of electrical resistivity and other logs) in the Atlantic. Sites 556 and 558 are in 37-m.y.-old seafloor, sites $395 \mathrm{~A}$ and $396 \mathrm{~B}$ are in $7-\mathrm{m}$.y.-old crust, and site 417D is 100 m.y. old.

The model provides us with a hope for the future. Geophysical logging will become standard in every drillhole of the next phase of deep ocean drilling, whereas in situ permeability measurements will not be done routinely. Instead, these measurements can be made selectively to further substantiate the fracture porosity-permeability analogy. Thus we hope that the next 10 years will lead to a profound understanding of the variation of permeability with depth and age in the oceanic crust and subsequently, of the hydrothermal convection system which it controls.

\section{Appendix: The Slug Test Theory}

Consider a well at hydrostatic pressure which is suddenly pressurized by injecting an additional amount of water with a high-pressure pump. The system is then shut in and the excess pressure $(H)$ following the initial pressure pulse $\left(H_{0}\right)$ is monitored as it decays with time $(t)$. It is assumed that flow into the tested interval is primarily radial and that the hydraulic properties of the formation remain constant throughout the test. Another assumption is that volumetric changes due to the expansion and contraction of components of the system other than the fluid are negligible. The normalized pressure decay $\left(H / H_{0}\right)$ is shown by Cooper et al. [1967] and Bredehoeft and Papadopulos [1980] to be a function of two parameters, alpha and beta, defined as

$$
\alpha=\frac{\pi r_{s}^{2} S}{V_{w} C_{w} \rho_{w} g} \quad \beta=\frac{\pi T t}{V_{w} C_{w} \rho_{w} g}
$$

where

\footnotetext{
$r_{s}$ radius of the wellbore;

$S$ hydraulic storage coefficient of the tested interval;

$V_{w}$ volume of water pressurized;

$C_{w}$ compressibility of water;

$\rho_{w}$ density of water;

$g$ acceleration due to gravity;

$t$ time since initiation of pressure slug;

$T$ transmissivity of the formation.
}

Cooper et al. [1967], Papadopulos et al. [1973], and Bredehoeft and Papadopulos [1980] present a tabulation of the pressure decay function $\mathrm{H} / \mathrm{H}_{0}$ as a set of type curves, in which the shapes of different decay curves for varying alphas are shown as a function of $\mathrm{H} / \mathrm{H}_{0}$ and beta [see Anderson and Zoback, 1982, Figure 4]. Permeability $k$ is determined from the transmissivity $T$ by

$$
k=T c / b \mathrm{~m}^{2}
$$

where $c=\left[\mu / g \rho_{w}\right] \times 10^{-4} \mathrm{~m}^{2} / \mathrm{cm}^{2} ; \mu$ is fluid viscosity, in poise; and $b$ is thickness of the interval isolated by the packer.

A semilogarithmic plot of $H / H_{0}$ versus time is superimposed on the type curves and translated along the beta axis into a position to best fit one of the alpha curves [see Cooper et al., 1967]. The time, $t_{0}$, is read off at the point $\beta=1$, where the slug test data overlie the type curve for the appropriate alpha. Then from (A1) and (A2),

$$
k=\frac{V_{w} C_{w} \rho_{w} g c}{\pi t_{0} b}
$$

As pointed out by Papadopulos et al. [1973], selection of the wrong type curve is a potential problem with the Cooper et al. [1967] method. However, such an error results in only a small corresponding error in the determination of $T$. It does result in a large error in the determination of $S$, however, and the slug test is considered an inaccurate method for the determination of aquifer storage coefficient. The type curve fit is generally good enough to produce an accuracy in $T$ of approximately $\pm 33 \%$. We will produce an estimated error by intentionally misfitting the alpha curve by plus or minus one order of magnitude to produce error bars for our transmissivity values.

The comparison of the shape of the $H / H_{0}$ versus time curve to the type curve also gives a test of the success of the experiment. If a type curve cannot be fit to within an order of magnitude and/or the shape of the slug test curve differs significantly from that of the type curve, something went wrong with the experiment. Pressure decay curves from experiments in which extreme leakage occurs around a damaged packer result in dramatically different curve shapes from those of the slug test.

When conducting multiple slug tests, it is assumed that the decline in the system head preceding the last slug has stopped before injection of the next slug test or that this declining head can be extrapolated to the end of the test without significant error. The initial head change $H_{0}$ is superimposed on this declining head and both $H_{0}$ and $H(t)$ of the next slug are measured above the previous test's projection [see Bredehoeft and Papadopulos, 1980]. A failure to account for this changing datum can affect the shape of the data plot and thus result in an erroneous match to the type curves. In practice, if the initial head decline has slowed down sufficiently, it is usually possible to extrapolate the "tail" from a preceding pressure transient through the slug test by fitting it to a simple linear or exponential function. Alternatively, if two complete slug tests occur one after the other, one may fit the first slug test to a type curve and use the projection of that type curve to approximate the head decline upon which the second pulse is superimposed. We use this latter method above.

Acknowledgments. We thank the officers and crew of the D/V Glomar Challenger for the diligence and hard work necessary to carry out these experiments. We especially thank Pat Thompson of the Deep Sea Drilling Project for extraordinary effort on our behalf. This work was supported by the National Science Foundation under grant OCE-81-10919 and Joint Oceanographic Institutions, Inc., under grant 5-61289. Lamont-Doherty Geological Observatory contribution 3753 . 


\section{REFERENCES}

Alt, J. C., and C. Laverne, Alteration of the oceanic crust: Mineralogy and processes in DSDP hole 504B, Initial Rep. Deep Sea Drill. Proj., 83, in press, 1984.

Anderson, R. N., and M. D. Zoback, Permeability, underpressures, and convection in the oceanic crust near the Costa Rica Rift, eastern equatorial Pacific, J. Geophys. Res., 87, 2860-2868, 1982.

Anderson, R. N., M. G. Langseth, and J. G. Sclater, The mechanisms of heat transfer through the floor of the Indian Ocean, J. Geophys. Res., 82, 3391-3409, 1977.

Anderson, R. N., M. A. Hobart, and M. G. Langseth, Geothermal convection through the oceanic crust and sediments in the Indian Ocean, Science, 204, 828-832, 1979.

Anderson, R. N., et al., DSDP hole 504B, the first reference section over $1 \mathrm{~km}$ through layer 2 of the oceanic crust, Nature, 300, 589$594,1982$.

Anderson, R. N., H. O'Malley, and R. L. Newmark, Use of geophysical logs for quantıtative determination of fracturing, alteration, lithology and their effects on permeability in the upper oceanic crust, Initial Rep. Deep Sea Drill. Proj., 83, in press, 1984a.

Anderson, R. N., M. D. Zoback, S. H. Hickman, and R. L. Newmark, Permeability versus depth in the upper oceanic crust: In situ measurements in DSDP hole 504B, eastern equatorial Pacific, Initial Rep. Deep Sea Drill. Proj., 83, in press, $1984 b$.

Becker, K., et al., In situ electrical resistivity and bulk porosity of the oceanic crust, Costa Rica Rift, Nature, 300, 594-598, 1982.

Becker K., M. G. Langseth, R. P. von Herzen, and R. N. Anderson, Deep crustal geothermal measurements, hole 504B, Costa Rica Rift, J. Geophys. Res., 88, 3447-3457, 1983.

Bredehoeft, J. D., and I. S. Papadopulos, A method for determining the hydraulic properties of tight formations, Water Resour. Res., 16, 233-238, 1980.

Cooper, H. H., Jr., J. D. Bredehoeft, and I. S. Papadopulos, Response of a finite diameter well to an instantaneous charge of water, Water Resour. Res., 3, 267-269, 1967.

Fehn, U., K. E. Green, R. P. Von Herzen, and L. M. Cathles, Numerical models for the hydrothermal field at the Galapagos Spreading Center, J. Geophys. Res., 88, 1033-1048, 1983.

Gartling, D. K., Convective heat transfer analysis by the finite element method, Comput. Methods Appl. Mech. Eng., 12, 365-382, 1977.

Gartling, D. K., and C. E. Hickox, MARIAH-A finite element program for incompressible porous flow problems, Rep. SAND791622, Sandia Lab., Albuquerque, N. M., 1979.

Hickman, S. H., M. G. Langseth, and J. F. Svitek, In situ permeability and pore pressure measurements near the Mid-Atlantic Ridge,
DSDP site 395, Initial Rep. Deep Sea Drill. Proj., 78B, 699-708, 1984.

Macdonald, K. C., and B. P. Luyendyk, The crest of the East Pacific Rise, Sci. Am., 244, 100-117, 1981.

Moos, D., and M. D. Zoback, In situ studies of velocity in fractured crystalline rock, J. Geophys. Res., 88, 2345-2358, 1983.

Newmark, R. L. R. N. Anderson, D. Moos, and M. D. Zoback, Sonic and ultrasonic logging in hole 504B and its implications for the structure, porosity, and stress regime of the upper $1 \mathrm{~km}$ of the oceanic crust, Initial Rep. Deep Sea Drill. Proj., 83, in press, 1984.

Papadopulos, I. S., J. D. Bredehoeft, and H. H. Cooper, On the analysis of slug test data, Water Resour. Res., 9, 1087-1089, 1973.

Rıbando, R. J., K. E. Torrence, and D. L. Turcotte, Numerical models for hydrothermal circulation in the oceanic crust, J. Geophys. Res., $81,3007-3012,1976$.

Sayles, F., and W. Jenkins, Helium and radon anomalies caused by convection of pore waters in sediments from the Guatemala Basin Science, 216, 136-141, 1982.

Seeburger, D. A., and M. D. Zoback, The distribution of natural fractures and joints at depth in crystalline rock, $J$. Geophys. Res., $87,5517-5534,1982$.

Staudigal, H., and S. R. Hart, Dating of oceanic crust hydrothermal alteration: Strontium isotope ratios from 504B carbonates and a re-interpretation of $\mathrm{Sr}$ isotope data from DSDP sites 105, 332B, 417, and 418, Initial Rep. Deep Sea Drill. Proj., 83, in press, 1984.

Von Herzen, R. P., T. J. Francis, and K. Becker, Long-spacing electrical resistivity at site 504B, Initial Rep. Deep Sea Drill. Proj., 69, 237-244, 1983.

Zoback, M. D., and R. N. Anderson, The implications of fracture distribution, structure and stratigraphy from borehole televiewer imagery of the oceanic crust on the Costa Rica Rift, Nature, 295, $375-379,1982$.

R. N. Anderson and R. L. Newmark, Borehole Research Group, Lamont Doherty Geological Observatory, Columbia University, Palisades, NY 10964.

S. H. Hickman, Department of Earth, Atmospheric, and Planetary Sciences, Massachusetts Institute of Technology, Cambridge, MA 20139.

M. D. Zoback, Department of Geological Sciences, Stanford University, Stanford, CA 94025.

(Received March 20, 1984; revised September 18, 1984; accepted September 20, 1984.) 